\title{
Massive Disseminated Tuberculosis in an Immunocompetent Patient: Early Diagnostic and Empiric Treatment Approach from an Endemic Country: Indonesia (A Case Report and Literature Review)
}

\author{
İmmünkompetent Bir Hastada Masif Yaygın Tüberküloz: Endemik Bir Ülke \\ Endonezya'dan Erken Tanı ve Ampirik Tedavi Yaklaşımı (Olgu Sunumu ve \\ Literatür Değerlendirmesi)
}

Allen Widysanto', Audrey Suryani Soetjipto², Nata Pratama Lugito ${ }^{3}$

\begin{abstract}
Tuberculosis is still rampant, despite the centuries of efforts to conquer it. Indonesia is host to the third highest TB burden in the world, with an uneven distribution of health care access, and especially to highly sensitive and specific molecular investigations. Rapid and accurate TB diagnosis is crucial for the control of the infection. An AFB smear test is easily accessed and is cost-effective, although there are a number of shortcomings with the approach. We report here on a case of negative acid-fast bacilli (AFB) smear disseminated tuberculosis (TB) in a previously healthy 23 year-old Indonesian female who presented to a secondary care facility with pulmonary, pericardial, peritoneal, utero-ovarian, genitourinary and splenic involvement. The clinician chose to start antituberculosis therapy without a positive microbiology and biopsy for bacterial load containment purposes, considering also the patient's clinical and endemic epidemiology. The diagnosis was confirmed with a positive mycobacterial culture after the initiation of anti-tuberculosis therapy. In the present study, we also review the diagnosis of 20 other cases of disseminated tuberculosis reported in other countries.
\end{abstract}

Key words: Disseminated TB, diagnosis, endemic, immunocompetent.
Özet

Tüberküloz (TB), yüzyıllardır bu hastalı̆ı̆ yenmek için verilen çabalara rağmen hala yaygındır. Endonezya, sağlık hizmetlerine; özellikle de yüksek derecede duyarlı ve spesifik moleküler araştırmaya erişime eşit olmayan bir dağılımıyla, dünyadaki toplam TB yükünün en yüksek olduğu üçüncü ülkedir. Enfeksiyonun kontrol altına alınması için hızlı ve doğru TB tanısı çok önemlidir. ARB smear testi (balgam yayma), kolayca erişilebilir ve uygun maliyetli bir testtir. Ancak, bazı eksiklikleri vardır. Akciğer, perikardiyal, peritoneal, utero-over, genitoüriner ve dalak tutulumu ile ikinci basamak bir sağlık tesisine başvuran, öncesinde sağlıklı 23 yaşındaki Endonezyalı bir kadında, ARB yayma negatif dissemine tüberküloz (TB) saptadığımız olguyu sunuyoruz. Klinisyen, hastanın kliniği ve hastalığın endemik epidemiyolojisini göz önüne alarak, pozitif mikrobiyoloji ve tanısal biyopsi sonucu olmadan anti-tüberküloz tedavisine başlamayı tercih etti. Anti-tüberküloz tedavinin başlanmasından 2 ay sonra ortaya çıkan pozitif mikobakteriyel kültür ile tanı doğrulandı. Ayrıca, diğer ülkelerden bildirilen 20 adet immünokompetan dissemine tüberkülozuları da inceledik.

Anahtar Sözcükler: Yaygın tüberküloz, tanı, endemik, immünkompetent.
'Department of Pulmonary and Respiratory Medicine, Siloam Lippo Village Karawaci, Pelita Harapan University, Tangerang, Indonesia

${ }^{2}$ General Practitioner, Pelita Harapan University, Tangerang, Indonesia

${ }^{3}$ Department of Internal Medicine, Siloam Lippo Village Karawaci, Pelita Harapan University, Tangerang, Indonesia
'Siloam Lippo Village Karawaci, Pelita Harapan Üniversitesi, Göğüs Hastalıkları Bölümü, Tangerang, Endonezya

${ }^{2}$ Pelita Harapan Üniversitesi, Pratisyen Hekim, Tangerang, Endonezya

${ }^{3}$ Siloam Lippo Village Karawaci, Pelita Harapan Üniversitesi, $\dot{I}_{\text {ç Hastalıkları Kliniği, Tangerang, Endonezya }}$

Submitted (Başvuru tarihi): 08.05.2019 Accepted (Kabul tarihi): 24.06.2019

Correspondence (iletişim): Allen Widysanto, Department of Pulmonary and Respiratory Medicine,

Siloam Lippo Village Karawaci, Pelita Harapan University, Tangerang, Indonesia

e-mail: allenwidy@yahoo.co.id 
Tuberculosis is one of the 10 leading causes of mortality in the world. A TB prevalence survey estimates Indonesia's burden at 842,000 incidences and 107,000 mortalities in 2017, placing it third in the world in terms of total TB burden after India and China (1). Indonesia has an uneven distribution of health care access, especially to facilities offering highly sensitive and specific molecular investigations. Tuberculosis remains rampant, despite centuries of efforts to conquer it. Rapid and accurate TB diagnosis is crucial for the control of the infection. Detecting and treating disseminated tuberculosis in immunocompetent patients would result not only in major reductions in morbidity, but also the economic burden on society (2).

\section{CASE}

A previously healthy 23-year-old Indonesian female presented with intermittent low-grade fever for one month, and associated progressive abdominal distention, unexplained weight loss (45 kg to $39 \mathrm{~kg}$ ), cough with minimal sputum, and loose stool 4-5 times per day without mucus or blood. There was no significant past medical history or family history of tuberculosis, and no history of steroid use or immunity to suppressive therapy. The patient was not habituated to chronic intakes of alcohol. She had previously been treated with multiple broad-spectrum antibiotics.

Upon physical examination, the patient was cachexic with a BMl of $16.9 \mathrm{~kg} / \mathrm{m}^{2}$. Her vital signs were normal with an O2 saturation of $96 \%$ in room air. Neither rhonchi nor wheezing was noted. She had pallor and a bilateral peripheral pitting edema on the lower extremities. Her abdomen was slightly distended but without organomegaly. Initial blood investigations were as follows: Hemoglobin, $8.10 \mathrm{~g} / \mathrm{dL}$; hematocrit, $25.9 \%$; WBC, $6.22 \times 10^{3} \mathrm{cell} / \mu \mathrm{L}$ with differential Basophil/ Eosinophil/ Band neutrophil/ Segment neutrophil/ Lymphocyte/ Monocyte = 0/0/3/75/15/7; MCV, 79.1 fL; urea, $19 \mathrm{mg} / \mathrm{dL}$; creatinine, $0.55 \mathrm{mg} / \mathrm{dL}$; ESR $90 \mathrm{~mm} /$ hours; SGOT, $72 \mathrm{U} / \mathrm{L}$; SGPT, $38 \mathrm{U} / \mathrm{L}$; albumin, $2.90 \mathrm{~g} / \mathrm{dL}$; LDH, $617 \mathrm{U} / \mathrm{L}$; RBG, $103 \mathrm{mg} / \mathrm{dL} ;$ CRP, $83 \mathrm{mg} / \mathrm{dL}$; C3 complement, 122 $\mathrm{mg} / \mathrm{dL}$; C4 complement, $33 \mathrm{mg} / \mathrm{dL}$; antistreptolysin (ASTO), +200; tubex TF, 0 . The results of a urinalysis and fecal analysis were within normal ranges, as were the results of rheumatoid factor and malaria rapid diagnostic tests. A serology test for HIV was negative. A sputum AFB smear was negative. A T-spot TB result was positive. A chest $X$-ray showed miliary distribution and cardiomegaly (Figure la).
An abdominal dual-source computed tomographic (DSCT) scan with contrast revealed a multiple occulted fluid accumulation with a thickened peritoneum, omentum and proximal ileum loop wall associated with a multiple enlargement of the mesenterial lymph nodes in the left quadrant $( \pm 1.05 \mathrm{~cm})$. A tortuous tubular structure filled with fluid and a contrast enhancement at the right and left adnexa were present. A kinking at the right proximal ureter at level L3 with thickened wall contrast enhancement, stenosis of the right distal ureter at level $\mathrm{L} 5 / \mathrm{S} 1$, and right hydroureter and grade II hydronephrosis were identified. Multiple hypodense nodules $(0.5 \mathrm{~cm})$ in the spleen were also noted. (Figure 2)

An echocardiogram revealed normal left and right ventricle function, a left ventricle ejection fraction of $68 \%$, global normokinetic and a mild pericardial effusion with no sign of tamponed and constriction.

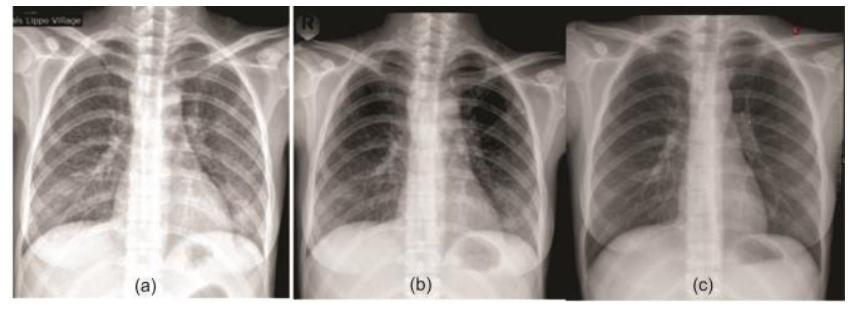

Figure 1: Chest $X$-ray showing miliary distribution on admission (a), a remarkable chest $X$-ray 2 month after anti-tuberculosis (b); and a remarkable chest $X$-ray at 12 months following anti-tuberculosis (c)

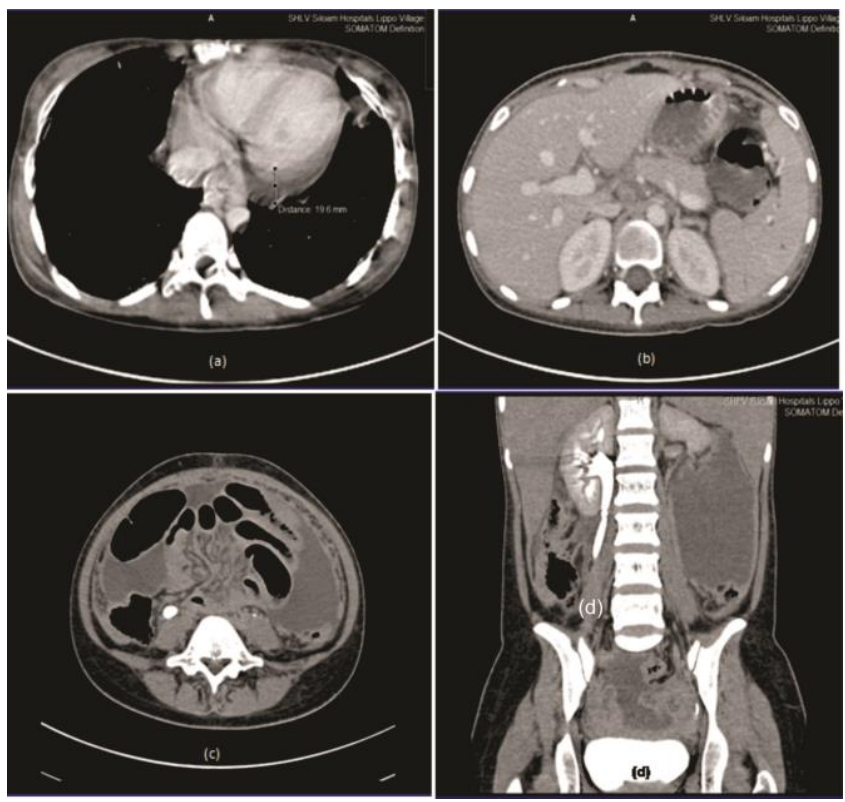

Figure 2a: CT scan showing a pericardial effusion (a); Abdominal CT scan showing multiple hypodense nodules $(0.5 \mathrm{~cm})$ on the spleen (b); Abdominal CT scan showing loculated ascites (c); Abdominal CT scan showing kinking of the right proximal ureter at level L3 (d) 
A diagnosis of disseminated tuberculosis with miliary, pericardial, spleen, colon, genitourinary and ovarian involvement was made. The patient was started on the standard anti-tuberculosis treatment regimen as per the protocol of the Indonesia National TB program: Rifampicin, 450 mg; Isoniazid, 300 mg; Pyrazinamide, 1000 mg; and Ethambutol, $1000 \mathrm{mg}$ daily for 2 months. This was followed by Rifampicin and Isoniazide for 9 months. A four-day course of methylprednisolone $62.5 \mathrm{mg}$ was administered intravenously three times a day.

One month after the initiation of treatment, the patient's symptoms were seen to improve. The patient started to gain weight, no low-grade fever was seen and the abdominal distention was reduced.

A further two months later, a mycobacterial culture confirmed the growth of Mycobacterium tuberculosis, which was sensitive to the standard treatment. A blood investigation revealed normal WBC and ESR. The lymphocyte count was normal. A chest $\mathrm{X}$-ray in the second month showed an excellent resolution of the pulmonary lesions (Figure 1b). The albumin level was normal. In the 12th month, the results of a chest X-ray (Figure 1c) and abdominal CT (Figure 3) scan were remarkable, and the patient's symptoms had resolved completely.

\section{Systematic search of literature}

The author conducted a search of PubMed (National Library of Medicine, Bethesda, MD, USA) with the following filters: publication from 2008 onwards, full text, case report and human study. Two searches were made using the terms "disseminated tuberculosis"; "disseminated tuberculosis" AND "immunocompetent", which resulted in 442 articles. These articles were screened, without blinding, by title and abstract review to identify any relevant studies. Studies of children and patients immunocompromised due to HIV, those detailing chronic infections such as diabetes mellitus, chronic kidney disease, cirrhosis, cancer, HIV, immunosuppressed patients and those under chemotherapy were excluded. Only the articles that included patients who fulfilled the criteria (below) for disseminated tuberculosis were included for analysis. Disseminated tuberculosis was defined as tuberculosis infection involving the blood stream, bone marrow, liver, two or more non-contiguous sites, or miliary TB.

\section{Data extraction}

The following data was garnered from the selected cases: (a) publication details (title, authors, year of publication, country); (b) number of case reported in each publication; (c) age and gender; (d) duration of symptoms; (e) consti- tutional symptom (fever, anorexia, weight loss, night sweat, fatigue); (f) pulmonary symptoms (cough, dyspnea) (g) organ involvement; (h) comorbidities; (i) pleural fluid analysis; (g) microbiologic test for sputum and other samples (smear and culture); (i) tissue biopsy; (i) chest Xray; (k) Mantoux test; (I) molecular testing (GeneXpert); (m) interferon gamma; (n) CT scan imaging; (o) antibiotic treatment; ( $\mathrm{k}$ ) anti-tuberculosis treatment and onset of drug time and duration; and (I) outcome.

Statistical analysis

Continuous data is presented as mean (SD) or median (range or IQR), and categorical data as percentages and proportions. All statistical analyses were carried out using the SPSS IBM version 21 statistical software package.

\section{Result}

We identified 20 disseminated tuberculosis cases involving immunocompetent patients (3-22). Cases for which full information was not available were treated as "not available". The study included 10 males and 10 females with a mean age of $34.4 \pm 15.7$ years. The patients had symptoms for a median of 4.7 months (range 0.5-24 months) prior to presentation to the hospital. Constitutional symptoms were experienced by $80 \%(16 / 20)$ of the patients, and were recorded as fever $(14 / 16 ; 87.5 \%)$, anorexia $(3 / 16 ; 18.7 \%)$, weight loss $(13 / 16 ; 81.2 \%)$, fatigue $(4 / 16 ; 25 \%)$ and night sweats $(3 / 16 ; 18.7 \%)$. Respiratory symptoms of disseminated TB with lung involvement were experienced by $85.7 \%(12 / 14)$ of the patients, including cough $(10 / 12 ; 83.3 \%)$ and dyspnea $(4 / 12 ; 33.3 \%)$. The lungs $(14 / 20 ; 70 \%)$ were the most involved organs in disseminated TB, followed by lymph nodes $(12 / 20 ; 60 \%)$, pleura $(6 / 20 ; 30 \%)$, liver (5/20; $25 \%)$, bone $(4 / 20 ; 20 \%)$ and spleen $(3 / 20 ; 15 \%)$.

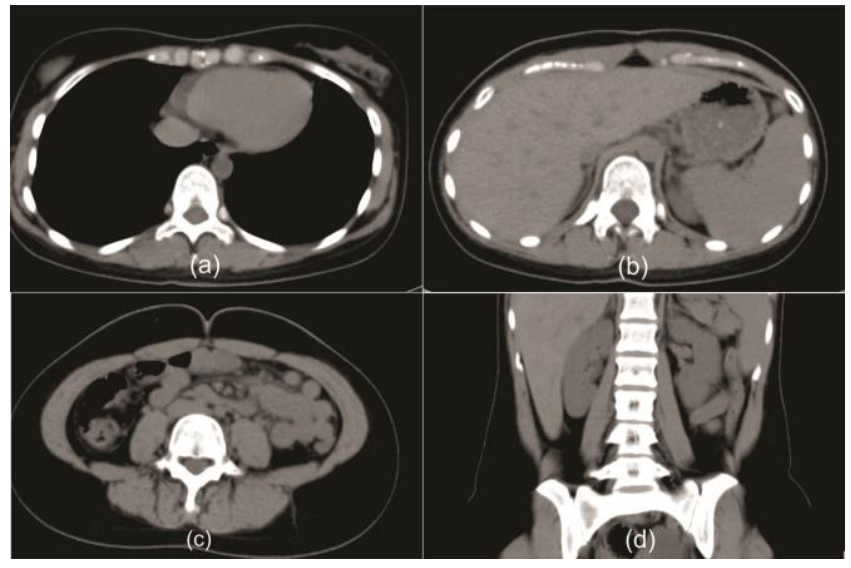

Figure 3: Non-contract CT scan following 12 month anti-tuberculosis treatment showing no pericardial effusion (a); no spleen multiple hypodense nodule (b); no loculated ascites (c); no hydronephrosis (d) 


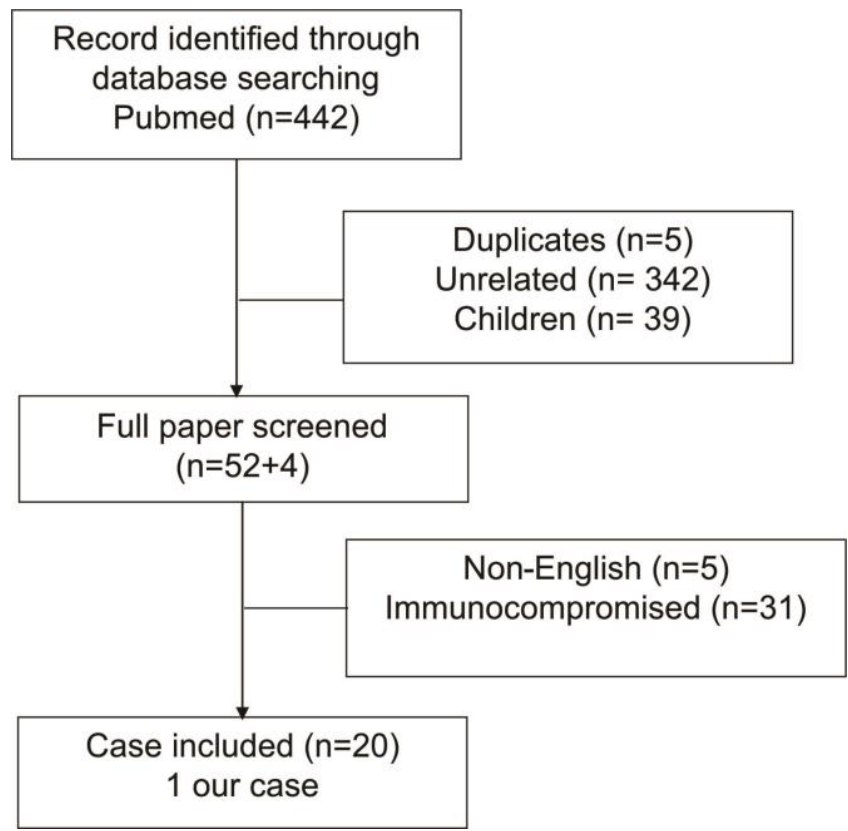

Figure 4: Literature search

A diagnosis of TB was established empirically with symptoms and radiology in $25 \%(5 / 20)$ of cases, microbiology smear in $25 \%(5 / 20)$, biopsy in $35 \%(7 / 20)$, serology in $5 \%(1 / 20)$, and in combinations of all modalities in $10 \%$ $(2 / 20)$ of the cases.

A sputum or pus AFB smear was done in $70 \%(14 / 20)$ cases, of which $50 \%(7 / 14)$ yielded a positive result. A culture was done in $40 \%(8 / 20)$ of cases, resulting in $50 \%(4 / 8)$ positive results. A fluid analysis was made in $20 \%(4 / 8)$ of cases, resulting in $100 \%(4 / 4)$ positive results. A chest $X$-ray was done in $55 \%(11 / 20)$ of cases, resulting in a $100 \%$ suggestion for TB, which were pleural effusion $(3 / 11 ; 27.2 \%)$, infiltrate $(4 / 11 ; 36.3 \%)$, reticulonodular $(3 / 11 ; 27.2 \%)$ and miliary $(9 \% ; 1 / 11)$. A Mantoux test was carried out in $25 \%$ (5/20) of cases, resulting in $60 \%$ positive results. GeneXpert was done in $20 \%$ $(4 / 20)$ of cases, resulting in $100 \%$ positive results. An interferon gamma release assay (IGRA) was done in 15\% $(3 / 20)$ of cases, resulting in $100 \%$ positive results. After appropriate anti-tuberculosis treatment, all cases saw significant improvement.

\section{DISCUSSION}

The diagnosis of disseminated TB can be challenging, since the AFB smear was positive in fewer than $20 \%$ of the suspected cases (23). The early initiation of antituberculosis treatment without a positive AFB result is both diagnostically and therapeutically problematic. The various symptoms of tuberculosis and the limited diagnostic tools, especially in rural areas, are significant problems in the establishment of a TB diagnosis.

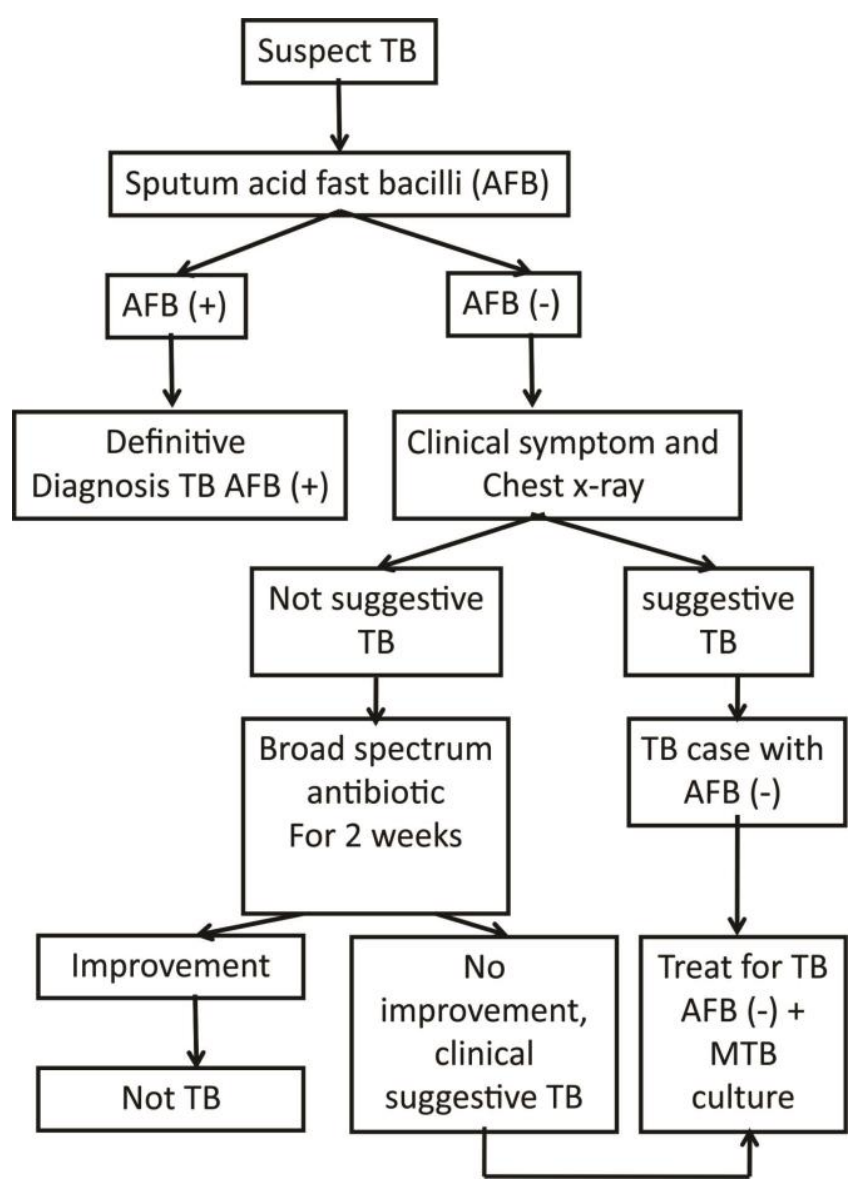

Figure 5: Diagnostic algorithm for tuberculosis in Indonesia

Delayed diagnosis results in delayed treatment. Virenfeldt et al. (24) reported that the delayed treatment group was significantly associated with a higher clinical severity at admission. More severe tuberculosis was found in the $<12.1$ weeks group $(20.8 \%)$ than in the $>12.1$ weeks group (33.9\%).

The AFB smear test is easily accessed and cost-effective, although it has a number of shortcomings. An AFB smear requires 5,000-10,000 bacteria/mL for detection, but is still unable to distinguish between TB and non-TB Mycobacterium (25). Obtaining a sample from extra pulmonary tuberculosis may be challenging due to the relatively inaccessible infection site, and the yield showed insufficient sensitivity (22-78\%) to establish a tuberculosis diagnosis $(23,25)$.

In our literature review, $14.2 \%$ of patients with respiratory involvement had no respiratory symptoms. This could be another challenge in obtaining samples despite pulmonary involvement. Our patient recorded three negative AFB smear results, with is consistent with the findings of our study review in which only $50 \%(7 / 14)$ of cases had a positive AFB smear. 
Table 1: Laboratory examination results

\begin{tabular}{|c|c|c|c|c|}
\hline \multirow[t]{2}{*}{ Variable } & \multicolumn{3}{|c|}{ Value } & \multirow[t]{2}{*}{ Normal range } \\
\hline & On admission & $\begin{array}{l}4 \text { days after } \\
\text { admission }\end{array}$ & $\begin{array}{c}2 \text { months after } \\
\text { admission }\end{array}$ & \\
\hline Hemoglobin (g/dL) & 8.10 & 8,0 & 12 & $11.70-15.50$ \\
\hline Hematocrit (\%) & 25,9 & 25,70 & 36.4 & $35.00-47.00$ \\
\hline Red blood cell (cell/ $\mu \mathrm{L})$ & $3,45 \times 106$ & $3,23 \times 106$ & 4.38 & $3.80-5.20$ \\
\hline White blood cell (cell/ $\mu \mathrm{L})$ & $6.22 \times 103$ & $4,90 \times 103$ & 4.96 & $3.60-11.00$ \\
\hline Basophil (\%) & 0 & N/A & 0 & $0-1$ \\
\hline Eosinophil (\%) & 0 & N/A & 4 & $1-3$ \\
\hline Band neutrophil (\%) & 3 & N/A & 3 & $2-6$ \\
\hline Segment neutrophil (\%) & 8.10 & $\mathrm{~N} / \mathrm{A}$ & 62 & $50-70$ \\
\hline Lymphocyte (\%) & 15 & N/A & 32 & $25-40$ \\
\hline Monocyte (\%) & 7 & N/A & 8 & $2-8$ \\
\hline Platelet (cell/ $\mu \mathrm{L}$ ) & $389 \times 103$ & $435 \times 103$ & 191 & $150-440$ \\
\hline MCV (fL) & 79,1 & 75,1 & 83.1 & $80-100$ \\
\hline $\mathrm{MCH}(\mathrm{pg})$ & 24,6 & 23,5 & 27.4 & $26-34$ \\
\hline$M C H C(g / d L)$ & 31,1 & 31,3 & 33 & $32-36$ \\
\hline ESR (mm/hours) & 90 & N/A & 15 & $0-20$ \\
\hline Urea (mg/dL) & 19 & N/A & & $<50$ \\
\hline Creatinine $(\mathrm{mg} / \mathrm{dL})$ & 0.55 & $\mathrm{~N} / \mathrm{A}$ & & $0.5-1.1$ \\
\hline EGFR $(\mathrm{mL} / \mathrm{min} 1.73 \mathrm{~m} 2)$ & 145.6 & $N / A$ & & $\begin{array}{l}>=60: \text { normal } \\
\text { kidney function }\end{array}$ \\
\hline Uric acid (mg/dL) & 4.1 & $\mathrm{~N} / \mathrm{A}$ & & $2.6-6.0$ \\
\hline SGOT & 72 & 34 & 43 & $5-34$ \\
\hline SGPT (U/L) & 38 & 45 & 40 & $0-55$ \\
\hline Albumin (g/dL) & 2.90 & 3.07 & 4.18 & $3.5-5.0$ \\
\hline Globulin (g/dL) & $N / A$ & 3.69 & 3.52 & $2.0-3.50$ \\
\hline Albumin/globulin ratio & $\mathrm{N} / \mathrm{A}$ & 0.83 & 1.19 & $1.20-2.2$ \\
\hline Total protein & $\mathrm{N} / \mathrm{A}$ & 6,76 & 7.7 & $6.40-8.30$ \\
\hline LDH (U/L) & 617 & $\mathrm{~N} / \mathrm{A}$ & & $135-214$ \\
\hline RBG (mg/dL) & 103 & $N / A$ & & $<200$ \\
\hline Natrium & 129 & 143 & 140 & $137-145$ \\
\hline Kalium & 3.7 & 4 & 3.7 & $3.6-5.0$ \\
\hline Chloride & 91 & 109 & 106 & $98-107$ \\
\hline Malaria rapid & Negative & $\mathrm{N} / \mathrm{A}$ & & Negative \\
\hline
\end{tabular}

The yields of mycobacterial culture in previous studies vary from $30 \%$ to $80 \%$ (25). Gaining a TB bacterial culture result can take 3-6 weeks, which is one of the main reasons for the diagnostic delay in AFB-negative patients (26). Our patient revealed a positive mycobacterium in his sputum culture after 2 months. In our literature review, a mycobacterium culture was carried out in $40 \%(8 / 20)$ of cases and resulted in a 50\% (4/8) positive result.

The low number of mycobacteria, together with difficulty in obtaining biopsy specimens from extrapulmonary TB lesions, often leads to a failure in detecting the TB bacilli, in addition to the difficulty in obtaining a biopsy specimen from an extrapulmonary TB lesion. In histopathological diagnoses, the presence of granulomas, caseation and the demonstration of AFB have been commonly used to define a positive test. However, a loss of immune function in the host can result in histopathologic findings demonstrating greater suppurative response and less well- formed granulomas. That said, granulomas can be seen also in non-tuberculous mycobacteria disease, fungal infections, brucellosis or syphilis, meaning that cautious interpretation is required (27).

Chest $\mathrm{X}$-rays are particularly useful in evaluating therapeutic response or disease progression in limited resource settings. Our review showed chest $\mathrm{X}$-ray had suggestive TB lesion in $11 / 11$ (100\%) of examinations, even in patients without respiratory symptoms. In eight cases, no chest $\mathrm{X}$-ray was made. These patients' chest $\mathrm{X}$-ray suggested miliary tuberculosis, despite the negative AFB result. Although many conditions can present with a miliary pattern on chest radiograph, miliary TB should be considered first in a geographically TB endemic area. Other imaging modalities such as ultrasonography and computed tomography are useful in assessing the extent of organ involvement. 
Table 2: Literature review of 20 cases disseminated tuberculosis in immunocompetent

\begin{tabular}{|c|c|}
\hline Age $(n=20)$ & $34,3 \pm 15,7$ \\
\hline Gender (male:female) $(n=20)$ & $10: 10$ \\
\hline Duration of symptom $(n=19)$, months & $4,7(0,5-24)$ \\
\hline \multicolumn{2}{|l|}{ Symptom at presentation } \\
\hline \multicolumn{2}{|l|}{ Constitutional $(n=20)$} \\
\hline Yes & $16 / 20(80 \%)$ \\
\hline No & $4 / 20(20 \%)$ \\
\hline \multicolumn{2}{|l|}{$\begin{array}{l}\text { Respiratory symptom of disseminated } \\
\text { TB with lung involvement }\end{array}$} \\
\hline Yes & $12 / 14(85,7 \%)$ \\
\hline No & $2 / 14(14,2 \%)$ \\
\hline \multicolumn{2}{|l|}{ Constitutional symptom $(n=16)$} \\
\hline Fever & $14 / 16(87,5 \%)$ \\
\hline Anorexia & $3 / 16(18,7 \%)$ \\
\hline Weight loss & $13 / 16(81,2 \%)$ \\
\hline Fatigue & $4 / 16(25 \%)$ \\
\hline Night sweats & $3 / 16(18,7 \%)$ \\
\hline \multicolumn{2}{|l|}{ Respiratory symptom $(n=12)$} \\
\hline Cough & 10/12 (83.3\%) \\
\hline Dyspnea & $4 / 12$ (33.3\%) \\
\hline \multicolumn{2}{|l|}{ Organ involvement $(n=20)$} \\
\hline Pericardial & $2 / 20(10 \%)$ \\
\hline Lung & $14 / 20(70 \%)$ \\
\hline Pleural & $6 / 20(30 \%)$ \\
\hline Lymph node & $12 / 20(60 \%)$ \\
\hline Peritoneal & $2 / 20(10 \%)$ \\
\hline Liver & $5 / 20(25 \%)$ \\
\hline Spleen & $3 / 20(15 \%)$ \\
\hline Genitourinary & $2 / 20(10 \%)$ \\
\hline Reproduction & $1 / 20(5 \%)$ \\
\hline Bone & $4 / 20(20 \%)$ \\
\hline Skin & $3 / 20(15 \%)$ \\
\hline \multicolumn{2}{|l|}{ AFB smear $(n=14)$} \\
\hline Positive & $7 / 14(50 \%)$ \\
\hline Negative & $7 / 14(50 \%)$ \\
\hline \multicolumn{2}{|l|}{ Culture $(n=8)$} \\
\hline Positive & $4 / 8(50 \%)$ \\
\hline Negative & $4 / 8(50 \%)$ \\
\hline \multicolumn{2}{|l|}{ Fluid analysis $(n=4)$} \\
\hline Positive & $4 / 4(100 \%)$ \\
\hline Negative & $0 / 4(0 \%)$ \\
\hline \multicolumn{2}{|l|}{ Chest X-ray $(\mathrm{N}=11)$} \\
\hline Pleural effusion & $3 / 11(27,2 \%)$ \\
\hline Infiltrate & $4 / 11(36,3 \%)$ \\
\hline Reticulonodular & $3 / 11(27,2 \%)$ \\
\hline Miliary & $1 / 11(9 \%)$ \\
\hline \multicolumn{2}{|l|}{ Biopsy $(n=13)$} \\
\hline Yes & 13/13 (100\%) \\
\hline No & $0 / 13(0 \%)$ \\
\hline \multicolumn{2}{|l|}{ Positive mantoux test $(n=5)$} \\
\hline Yes & $3 / 5(60 \%)$ \\
\hline No & $2 / 5(40 \%)$ \\
\hline \multicolumn{2}{|l|}{ GeneXpert $(n=4 / 20)$} \\
\hline Positive & $4 / 4(100 \%)$ \\
\hline No & $0 / 4(0 \%)$ \\
\hline \multicolumn{2}{|l|}{ INF-gamma $(n=3 / 20)$} \\
\hline Positive & $3 / 3(100 \%)$ \\
\hline Negative & $0 / 3(0 \%)$ \\
\hline \multicolumn{2}{|l|}{ CT scan } \\
\hline \multicolumn{2}{|l|}{ Mode of diagnosis $(n=20)$} \\
\hline Empiric & $5 / 20(25 \%)$ \\
\hline Biopsy & $7 / 20(35 \%)$ \\
\hline Microbiology (smear and culture) & $5 / 20(25 \%)$ \\
\hline Serology (IGRA/mantoux) & $1 / 20(5 \%)$ \\
\hline All options & $2 / 20(10 \%)$ \\
\hline
\end{tabular}

In our review, constitutional symptoms were found in $80 \%$ of cases, which can be a valuable marker in TBsuspected patients. A similar result was reported in a limited Ugandan resource setting, where constitutional TB symptoms, including fever, weight loss and excessive night sweats were significantly useful as clinical predictors of empirical anti-tuberculosis initiation in TB/HIV patients with a negative AFB smear (28).

Five cases TB were treated empirically without initial microbiological evidence $(3,5,9,14,15)$.

Das et al. (3) reported on a 19-year-old male in India with disseminated tuberculosis involving the left pleura, pericardium, peritoneum and intraabdominal lymph nodes. The patient presented with high fever and shortness of breath for 1 month. Disseminated TB was diagnosed after an entire abdomen ultrasonography (USG) showed ascites with multiple thin and thick septa and multiple enlarged para- and pre-aortic lymph nodes, in combination with a chest radiograph showing a pericardial effusion in spite of a negative AFB sputum test. Antituberculosis drug category I was administered.

Kesav et al. (9) reported on a patient in India with a holocranial non-throbbing headache, apathy, executive dysfunction and reduced social interaction for the past 1 month. No respiratory symptoms were found. A chest CT scan showed miliary nodules with mediastinal lymphadenopathy. The patient had no productive sputum, and so an AFB sputum smear could not be obtained. Cerebrospinal ADA was 25 and TB was diagnosed. The patient's symptoms improved dramatically within the first month of initiation of anti-tuberculosis therapy.

Dev et al. (14) reported on a case in India of milky urine and constitutional symptoms with negative acid fast bacilli. Imaging suggestive tuberculosis such as upper lobe infiltrates in chest $\mathrm{X}$-ray and enhancing in multiple abdominal organs in CT scan. A diagnosis of chyluria with disseminated tuberculosis was made based on the clinical picture and investigations, and the patient was initiated on antitubercular therapy.

Mearelli et al. (15) reported on a case in Denmark of prolonged fever, abnormal chest imaging suggestive of lung tuberculosis and evidence of dissemination, leading to a TB diagnosis.

Chamberlin et al. (5) reported on a 25-year-old Indian with worsening constitutional symptoms over 3 months. A conventional chest $X$-ray and $C T$ showed a right loculated pleural effusion, a right upper lobe density, a right-sided compressive atelectasis, multiple bilateral subcentimeter 
nodules, and a $1.5 \mathrm{~cm}$ right hepatic lesion. The patient had positive IGRA and Mantoux tests, despite the negative AFB smear and normal ADA levels. TB was diagnosed and improvement was observed after the initiation of anti-tuberculosis treatment.

Our review $(4,16-21)$ found that the majority of cases (35\%) diagnosed disseminated tuberculosis from a biopsy (7/20). Indonesia's National Tuberculosis Control Program, which was adopted from the WHO tuberculosis treatment guidelines, recommends that subject with a negative AFB but with clinical symptoms and a chest $X$-ray that is suggestive of TB, should be treated for tuberculosis smear-negative with further mycobacteria culture confirmation.

Diagnosing extrapulmonary TB might be an intricate process (23). In this case, a chronic cough with progressive wasting and a chest $\mathrm{X}$-ray suggesting miliary tuberculosis led to the identification of TB infection as a working diagnosis. Although the AFB smear was negative, an MTB culture revealed a positive result 2 months later.

Conclusion

In endemic countries, especially Indonesia, a high index of clinical suspicion, early diagnosis and timely institution of anti-tuberculosis treatment is crucial for the prognosis of disseminated tuberculosis. Symptoms and radiology findings indicating TB should be diagnosed and treated if no bacteriological evidence of tuberculosis can be obtained.

Constitutional symptoms and serial chest $X$-rays can be a great modality for the diagnosis and evaluation of treatment response. Improving the diagnostic and case holding efficiencies of health facilities can reduce the risk of dissatisfactory outcome. Administering anti-tuberculosis agents in the early stages may sometimes be necessary in cases where the histological findings are inconsistent with TB-suspected clinical findings.

\section{ACKNOWLEDGEMENT}

George Mathew, Jokevin Prasetyadhi, Aurea Stella Soetiipto.

\section{CONFLICTS OF INTEREST}

None declared.

\section{AUTHOR CONTRIBUTIONS}

Concept - A.W., A.S.S., N.P.L.; Planning and Design A.W., A.S.S., N.P.L.; Supervision - A.W., A.S.S., N.P.L.; Funding - G.A., P.B.F.; Materials -; Data Collection and/or Processing - A.S.S.; Analysis and/or Interpretation - A.W., A.S.S., N.P.L.; Literature Review - A.W., A.S.S., N.P.L.; Writing - A.W., A.S.S. Critical Review - A.W., A.S.S., N.P.L.

\section{YAZAR KATKILARI}

Fikir - A.W., A.S.S., N.P.L.; Tasarım ve Dizayn - A.W., A.S.S., N.P.L.; Denetleme - A.W., A.S.S., N.P.L.; Kaynaklar - G.A., P.B.F.; Malzemeler -; Veri Toplama ve/veya işleme - A.S.S.; Analiz ve/veya Yorum - A.W., A.S.S., N.P.L.; Literatür Taraması - A.W., A.S.S., N.P.L.; Yazıyı Yazan - A.W., A.S.S.; Eleştirel İnceleme - A.W., A.S.S., N.P.L.

\section{REFERENCES}

1. WHO. Global Tuberculosis Report 2018. Geneva: World Health Organization;2018.

2. Collins D, Hafidz F, Mustikawati D. The economic burden of tuberculosis in Indonesia. Int J Tuberc Lung Dis 2017; 21:1041-8. [CrossRef]

3. Das SK, Das A, Gangopadhyay A, Sinha AK. Primary disseminated extrapulmonary multidrug resistant tuberculosis. Indian J Med Microbiol 2012; 30: 364-6. [CrossRef]

4. Rajasekharan C, Ajithkumar S, Anto V, Parvathy R. Extrapulmonary disseminated tuberculosis with tuberculous adrenalitis: a stitch in time saves nine. BMJ Case Rep 2013; 2013:1-4. [CrossRef]

5. Chamberlin K, Orfanos S, Mukheriee A, Moy E, Koganti $\mathrm{M}$, Khan W. A case of disseminated tuberculosis mimicking metastatic cancer. Respir Med Case Rep 2018; 25:239-41. [CrossRef]

6. Hashmani S, Tipoo Sultan FA, Msood MQ. Unusual presentation of a young man with disseminated tuberculosis and right ventricular mass. BMJ Case Rep 2016; 19:1-5. [CrossRef]

7. Li JC, Fong W, Wijaya L, Leung YY. Disseminated tuberculosis masquerading as a presentation of systemic lupus erythematosus. Int J Rheum Dis 2018; 21:352-5. [CrossRef]

8. Kaur A, Kucheria M, Gupta R, Thami GP, Kundu R. Extensive Multisystemic Disseminated Tuberculosis in an Immunocompetent Patient. J Clin Aesthet Dermatol 2018; $11: 42-6$.

9. Kesar P, Vishnu VY, Lal V, Prabhakar S. Disseminated tuberculosis presenting as rapidly progressive dementia. Q J Med 2014; 107:79-80. [CrossRef] 
10. Mendoza M, Sheele JM. An unusual presentation of disseminated Mycobacterium tuberculosis in the ED. Am J Emerg Med 2016; 34:1915-e5-7. [CrossRef]

11. Verma R, Patil TB, Lalla R. Disseminated tuberculosis manifesting as pulmonary, meningeal and spinal tuberculosis in an immunocompetent patient. BMJ Case Rep 2012; 2012:1-3. [CrossRef]

12. Goncalves R, Lopes P, Mendes P, Trepa J, Rua J, Sa R, et al. Miliary tuberculosis with cerebral, liver, prostate and retroesophageal involvement. ID Cases 2017; 9:25-7. [CrossRef]

13. Madhyastha SP, Gopalaswamy V, Acharya RV, Doddamani A. Disseminated tuberculosis in relatively asymptomatic young woman. BMJ Case Rep 2017; 2017:1-3. [CrossRef]

14. Dev N, Kumar R. Chyluria: A Rare Initial manifestation of disseminated tuberculosis. Int J Mycobacteriol 2018; 7:282-4. [CrossRef]

15. Mearelli F, Burekovic I, Zanetti M, Altamura N, Carlo G, Biolo $G$, et al. Disseminated tuberculosis in an immunocompetent patient. Int J Infect Dis 2013; 17:e784-6. [CrossRef]

16. Uribe-Bojanini E, Santa-Vélez C, Ruiz-Suarez A, BuchelyIbarra N. Patient with disseminated tuberculosis and rare perianal involvement. Actas Dermosifiliogr 2016; 107:874-6. [CrossRef]

17. Shaharir SS, Tumian NR, Yu Lin AB, Abdul Wahid SF. Disseminated tuberculosis masquerading primary myelodysplastic syndrome. J Infect Dev Ctries 2013; 7:286-8. [CrossRef]

18. Kulshreshtha D, Raj $G$, Singh $S$, Kumar Maurya $P$, Singh AK, Thacker AK. Elevated CA-125 in disseminated tuberculosis: A case report. Q J Med 2015; 108:729-30. [CrossRef]

19. Kumar N, Aggarwal P, Dev N, Kumar G. Disseminated tuberculosis in a patient with antinuclear antibody- negative systemic lupus erythematosus: A rare association. BMJ Case Rep 2013; 2013:2012-4. [CrossRef]

20. Tekbas G, Abakay A, Tanrikulu AC, Firat U, Ekii F, Dostbil Z, et al. Skin ulcers: A sign of disseminated tuberculosis. Respir Care 2011 ; 56:1853-6. [CrossRef]

21. Huo N, Wu Z, Dong X, Feng L, Nong L, Wang H, et al. A 34-year-old obese woman with rash, finger swelling and fever. Int J Infect Dis 2017; 59:82-5. [CrossRef]

22. Singh J, Dinkar A. Positive outcome of pulmonary tuberculosis associated with extraordinary extensive extrapulmonary tuberculosis in an immunocompetent adult. Int J Mycobacteriol 2018; 7:183-5. [CrossRef]

23. Chakravorty S, Sen MK, Tyagi JS. Diagnosis of extrapulmonary tuberculosis by smear, culture, and PCR using universal sample processing technology. J Clin Microbiol 2005; 43:4357-62. [CrossRef]

24. Virenfeldt J, Rudolf F, Camara C, Furtado A, Gomes V, Aaby $P$, et al. Treatment delay affects clinical severity of tuberculosis: A longitudinal cohort study. BMJ Open 2014; 4:e004818. [CrossRef]

25. Behr M, Elwood K. Canadian Tuberculosis Standards. 7th ed. Canada: Public Heal Agency Canada; 2014.

26. Tyrrell FC, Budnick GE, Elliott T, Gillim-Ross L, Hildred MV, Mahlmeister $P$, et al. Probability of negative mycobacterium tuberculosis complex cultures based on time to detection of positive cultures : a multicenter evaluation of commercial-broth-based culture systems. J Clin Microbiol 2012; 50:3275-82. [CrossRef]

27. Lee JY. Diagnosis and treatment of extrapulmonary tuberculosis. Tuberc Respir Dis (Seoul) 2015; 78:47-55. [CrossRef]

28. Nakiyingi L, Bwanika JM, Kirenga B, Nakanjako D, Katabira $C$, Lubega $G$, et al. Clinical predictors and accuracy of empiric tuberculosis treatment among sputum smearnegative HIV-infected adult TB suspects in Uganda. PLoS ONE 2013; 8:e74023. [CrossRef] 